$\xi=\mathrm{\alpha}$

\title{
Primary mechanism responsible for age-dependent neuronal dehydration
}

\author{
Anna Nikoghosyan, Armenuhi Heqimyan, Sinerik Ayrapetyan * \\ UNESCO Chair-Life Sciences International Postgraduate Educational Center Yerevan, Armenia \\ *Corresponding author E-mail: info@biophys.am
}

\begin{abstract}
Neuronal dehydration and high $\left[\mathrm{Ca}^{2+}\right]_{\mathrm{i}}$ are essential hallmarks for age-dependent memory impairment. $\mathrm{Na}^{+} / \mathrm{K}^{+}$-ATPase, having membrane transporting and intracellular signaling functions, has age-induced dysfunctional character. Therefore, it could have a key role in age-dependent neuronal dehydration and increase of $\left[\mathrm{Ca}^{2+}\right]_{\mathrm{i}}$. However, it is not clear the dysfunction of which above mentioned functions of $\mathrm{Na}^{+} / \mathrm{K}^{+}$-ATPase serves as a primary mechanism for generation of age-dependent neuronal dehydration and increase of $\left[\mathrm{Ca}^{2+}\right]_{\mathrm{i}}$. In present work age-dependent effects of $\leq 10^{-9} \mathrm{M}$ (agonist for $\alpha_{3}$ isoform which has only signaling function) and $10^{-4} \mathrm{M}$ ouabain (agonist for $\alpha_{1}$ isoform which has ion-transporting function) on brain cortex tissue hydration, ${ }^{45} \mathrm{Ca}^{2+}$ uptake and ${ }^{45} \mathrm{Ca}^{2+}$ efflux through plasma membrane were studied. It was shown that $\leq 10^{-9} \mathrm{M}$ and $10^{-4} \mathrm{M}$ ouabain concentrations have stimulation effects on cortex tissue hydration and $\mathrm{Na}^{+} / \mathrm{Ca}^{2+}$ exchange in reverse mode. However, these effects have age-dependent weakening and increasing characters, respectively. It is suggested that $\leq 10^{-9} \mathrm{M}$ ouabain-induced tissue hydration is due to cAMP-activated $\mathrm{Ca}^{2+}$-ATPase in endoplasmic reticulum membrane leading to reversion of $\mathrm{Na}^{+} / \mathrm{Ca}^{2+}$ exchange and elevation of endogenous $\mathrm{H}_{2} \mathrm{O}$ release in cytoplasm. This effect has age-dependent depressing character. Thus, the dysfunction of $\alpha_{3}$ isoform-dependent intracellular signaling system could be considered as a primary mechanism for age-dependent neuronal dehydration.
\end{abstract}

Keywords: Brain Cortex; ${ }^{45} \mathrm{Ca}^{2+}$ Efflux; ${ }^{45} \mathrm{Ca}^{2+}$ Uptake; $\mathrm{Na}^{+} / \mathrm{K}^{+}$-ATPase $\mathrm{A}_{3}$ Isoform; Tissue Hydration.

\section{Introduction}

Age-induced memory impairment during normal and pathological aging is one of the modern problems in neuroscience and has become a focal point for public health concern due to the aging of the world population.

The dysfunction of $\mathrm{Na}^{+} / \mathrm{K}^{+}$-pump, increase of $\left[\mathrm{Ca}^{2+}\right]_{\mathrm{i}}$, mitochondrial dysfunction and oxidative stress, increase of mitochondrial DNA and its damage, peroxidation of lipids, magnesium deficit, iron increase, formation of amyloid- $\beta(\mathrm{A} \beta)$ peptide and a number of other pathological changes in neurons described in literature are typical hallmarks for age-induced memory impairment which are accompanied by tissue dehydration [1]. However, which of the above mentioned mechanisms is primary in generation of ageinduced memory impairment and cell death cascade is not clear yet.

It is known that neuronal death in brain, like in other cells, occurs by two phases; neuronal swelling (hydration) [2], [3] which is followed by its shrinkage (dehydration) [4], [5].

Earlier we have shown that neuronal swelling in hypo-osmotic medium has a discrete character [6] which leads to the increase of the number of functionally active proteins in membrane, having receptors [7], enzymes [8] and ionic channels forming properties [9]. At present, it is established that in cell membrane there are caveolae, containing different enzymes which are activated as a result of cell swelling [10]. Cell hydration-induced intracellular macromolecules' activity by "folding-unfolding" mechanism is another powerful pathway for regulation of intracellular metabolic activity [4], [11]. On the basis of the previous data that neuronal swelling in response of activation of ligand- and potentialactivated ionic channels in neuronal membrane led to the increase of the number of $\mathrm{Na}^{+} / \mathrm{K}^{+}$-pump units $\left(\left[{ }^{3} \mathrm{H}\right]\right.$-ouabain binding sides) in membrane [8], neuronal swelling was suggested as a protective reaction of cell [12].

At present it is well established, that cell swelling triggers proliferation, while its shrinkage promotes cell apoptosis [13], [14]. In spite of multi-regulatory role of cell hydration in regulation of cell functional activity, the role of neuronal dehydration in agedependent memory impairment is contradictory and inconsistent [15].

The emerging evidence suggests that cell membrane is highly permeable for water, which is a universal messenger for signal transduction from bathing medium into intracellular metabolism. Because of the existence of special water channels (aqua pores) in membrane, water transport through membrane takes place much faster than predicted by simple osmotic diffusion [16]. Therefore, the osmotic gradient on membrane generated by extracellular or intracellular factors has a transient character and the factorinduced changes of intracellular water content are compensated by cell metabolism $[17,18,19,20]$, the dysfunction of which leads to cell pathology.

$\mathrm{Na}^{+} / \mathrm{K}^{+}$-pump, the dysfunction of which is a consequence of aging, has a key role in metabolic regulation of cell hydration [13], [10], [21], [22]. The latter is dictated by the facts that $\mathrm{Na}^{+} / \mathrm{K}^{+}$-pump has electrogenic character [23], [24] and generates $\mathrm{Na}^{+}$gradient on membrane which serves as an energy source for a number of sec- 
ondary ionic transporters in membrane, such as $\mathrm{Na}^{+} / \mathrm{H}^{+}, \mathrm{Na}^{+} / \mathrm{Ca}^{2+}$, $\mathrm{Na}^{+}$/sugars, amino acids and osmolytes [17], [18], [21], [22], [25]. On the other hand $\mathrm{Na}^{+} / \mathrm{K}^{+}$-pump, being the highest adenosine triphosphate (ATP) energy utilizing mechanism, determines the rate of metabolic cascades of ATP synthesis. The latter is accompanied by intensive release of endogenous $\mathrm{H}_{2} \mathrm{O}$ molecules in cytoplasm as a result of glucose oxidation [26]. Therefore, $\mathrm{Na}^{+} / \mathrm{K}^{+}$pump could be considered not only as an ion-transporting mechanism in cell membrane as it was suggested by classical membrane theory [27] but also as a powerful mechanism regulating cell hydration through intracellular signaling systems. However, it is not clear the depression of which function (membrane iontransporting or cytoplasm signaling system) of pump is a primary mechanism for age-induced neuronal dehydration.

Our previous study has shown that among three ouabain receptors $\left(\mathrm{Na}^{+} / \mathrm{K}^{+}\right.$-ATPase $)$, having low $\left(\alpha_{1}\right)$, middle $\left(\alpha_{2}\right)$ and high $\left(\alpha_{3}\right)$ af finities, $\alpha_{3}$ isoform-dependent signaling system controlling cell hydration serves as an extra-sensitive and universal sensor for different chemical and physical signals [28], [29] and has pronounced age-dependent character [30], [31]. Therefore, we hypothesize that the dysfunction of $\mathrm{Na}^{+} / \mathrm{K}^{+}$-ATPase $\alpha_{3}$ isoformdependent signaling system could serve as a primary mechanism for generation of age-dependent neuronal dehydration [28]. Thus, the aim of the present study is to check this hypothesis, which stems from and is a natural extension of our previously published findings. We believe that the elucidation of this mechanism will serve as a novel therapeutic target for counteracting age-dependent neuronal dehydration.

\section{Materials and methods}

\subsection{Animals}

All procedures performed on animals were carried out following the protocols approved by Animal Care and Use Committee of Life Sciences International Postgraduate Educational Centre (LSIPEC, Yerevan, Armenia).

Experiments were performed on 405 young (six weeks old) and 405 old (18 months old) male albino rats. They were regularly examined, kept under control of the veterinary in LSIPEC and reserved in a specific pathogen-free animal room under optimum conditions of $12 \mathrm{~h} \mathrm{light/dark} \mathrm{cycle,} \mathrm{at} \mathrm{temperature} \mathrm{of} 22 \pm 2^{\circ} \mathrm{C}$, a relative humidity of $50 \%$ and were fed ad libitum on a standard lab chow and water.

\subsection{Chemicals}

Tyrode's physiological solution (PS) containing (in $\mathrm{mM}$ ) 137 $\mathrm{NaCl}, 5.4 \mathrm{KCl}, 1.8 \mathrm{CaCl}_{2}, 1.05 \mathrm{MgCl}_{2}, 5 \mathrm{C}_{6} \mathrm{H}_{12} \mathrm{O}_{6}, 11.9 \mathrm{NaHCO}_{3}$, $0.42 \mathrm{NaH}_{2} \mathrm{PO}_{4}$ and adjusted to $\mathrm{pH} 7.4$ with $\mathrm{NaOH}$ was used. In order to receive $50 \% \mathrm{PS}, 68.5 \mathrm{mM}$ of $\mathrm{NaCl}$ was replaced with $2 \mathrm{M}$ of non-metabolizing substance mannitol dissolved in Tyrode's PS for maintaining the osmolarity of solution. All chemicals were obtained from "Medisar" Industrial Chemical Importation Company (Yerevan, Armenia). $\mathrm{K}^{+}$-free solution consisted of $5.4 \mathrm{mM}$ $\mathrm{NaCI}$ instead of $5.4 \mathrm{mM}$ KCI. ${ }^{45} \mathrm{Ca}^{2+}$ with specific activity $40 \mathrm{mCi} / \mathrm{ml}$ (PerkinElmer, Massachusetts, USA) was added in $\mathrm{K}^{+}$free solution containing $68.5 \mathrm{mM}(50 \%) \mathrm{NaCl}$ and used for the enrichment of tissue. $\left[{ }^{3} \mathrm{H}\right]$-ouabain with specific activity $(25.34$ $\mathrm{Ci} / \mathrm{mM}$ ) and non-radioactive ouabain (PerkinElmer, Massachusetts, USA) from $10^{-11} \mathrm{M}$ to $10^{-4} \mathrm{M}$ concentrations dissolved in physiological solution were used for intraperitoneal injections and tissues' incubation. ${ }^{45} \mathrm{Ca}^{2+}$ was used for intraperitoneal injections and tissues' incubation. The volume of injected solutions was adjusted according to the weight of animals $(0.02 \mathrm{ml} / \mathrm{g})$, samples were incubated in $10 \mathrm{ml}$ of experimental solution.

\subsection{Tissue preparation}

It is well known that anesthetics with different chemical and pharmacological profiles [32], [33], [34] significantly affect metabolic processes which play an important role in regulation of cell volume [13], [35]. Therefore, in present experiments animals were sharply immobilized by freezing method (dipping their noses into liquid nitrogen for 3-4 sec) and decapitated [36]. After such procedure the full absence of somatic reflexes on extra stimuli was recorded.

Based on our previous data [30] where the age-dependent kinetics of ouabain binding with $\alpha_{3}$ receptors in brain cortex tissue is more pronounced than in subcortex and cerebellum tissues (in adult animals) the investigation of brain cortex tissue has been the subject of the present study.

In vivo experiments, $30 \mathrm{~min}$ before decapitation animals were intraperitoneally injected with investigated solutions. After this they were immobilized and decapitated. Investigated brain cortex tissue was isolated and dissected into samples weighing from 50 to $70 \mathrm{mg}$. In vitro experiments animals were firstly immobilized and decapitated. Their brain cortex tissue samples were dissected in the same manner and then incubated in investigated solutions. For each experimental group five animals were chosen. 8 samples were dissected from brain cortex of each animal. Thus, the average data for 3 independent experiments was calculated based on the data obtained from the study of 120 brain slices (40x3).

\subsection{Definition of water content of brain tissues}

Water content of brain cortex tissue was determined by traditional "tissue drying" method [37]. After measuring the cortex tissue wet weight (w.w.), tissue was dried in oven (Factory of Medical Equipment, Odessa, Ukraine) for $24 \mathrm{~h}$ at $105^{\circ} \mathrm{C}$ for determination of dry weight (d.w.). The quantity of water in $1 \mathrm{~g}$ of d.w. tissue was counted by the following equation: (w.w. - d.w.) / d.w. [37].

\subsection{Counting $\left[{ }^{3} \mathrm{H}\right]$ ouabain receptors in membrane}

To estimate the number of $\mathrm{Na}^{+} / \mathrm{K}^{+}$-ATPase molecules in membrane, the number of $\left[{ }^{3} \mathrm{H}\right]$-ouabain molecules binding with cell membrane was counted. In vivo experiments $\left[{ }^{3} \mathrm{H}\right]$-ouabain was intraperitioneally injected to animals. After $30 \mathrm{~min}$ animals were sacrificed and brain slices were dissected and incubated in $100 \mathrm{ml}$ PS containing $1 \mathrm{mM}$ "cold" ouabain. To remove surface-adherent and extracellular tracer the brain slices were washed fivefold, each wash about $5 \mathrm{~min}$ in duration, in PS containing $1 \mathrm{mM}$ "cold" ouabain. After determination of wet and dry weights of samples, they were homogenized in $50 \mu \mathrm{l}$ of $68 \% \mathrm{HNO}_{3}$ solution. Then $2 \mathrm{ml}$ of Bray's scintillation fluid was added and chemoluminescence of samples was quantified with 1450-MicroBeta liquid scintillation counter (Wallac, Turku, Finland). The number of ouabain molecules binding with membranes of cells was defined per mg of dry weight of samples. The ouabain concentration injected to the animal was adjusted to animal body weight $\left(10^{-x} \mathrm{M} / \mathrm{g}\right.$ of animal weight, where $10^{-x}$ is the testing concentration of ouabain). The volume of the injected PS was also adjusted to the weight of animals $(0.2 \mathrm{ml} / \mathrm{g}$ of animal weight $)$. The lowest concentration of ouabain which was used in the experiments was $10^{-11} \mathrm{M}\left[{ }^{3} \mathrm{H}\right]$ ouabain (isotope). Higher concentrations of ouabain used in the experiments contained $10^{-11} \mathrm{M}\left[{ }^{3} \mathrm{H}\right]$ ouabain $+10^{-\mathrm{x}} \mathrm{M}$ cold (non-isotope) ouabain. Respective concentrations of ouabain used in vivo experiments were added in PS where brain slices were bathing.

\subsection{Measurement of ${ }^{45} \mathrm{Ca}^{2+}$ uptake and ${ }^{45} \mathrm{Ca}^{2+}$ efflux rate constant}

${ }^{45} \mathrm{Ca}^{2+}$ uptake by brain cortex tissue was measured by the following way: $0.0115 \mathrm{mM} \mathrm{CaCl}$ from $1.8 \mathrm{mM}$ was substituted by radioactive ${ }^{45} \mathrm{Ca}^{2+}(11.2 \mathrm{mCi} / \mathrm{l})$ in PS. In vivo experiments animals were intraperitioneally injected with ${ }^{45} \mathrm{Ca}^{2+}$ (with $0.187 \mathrm{mCi} / \mathrm{g}$ radioactivity of body weight). After $30 \mathrm{~min}$ animals were decapi- 
tated and brain samples were incubated in ouabain-free PS (as a control) and PS containing $10^{-9} \mathrm{M}$ and $10^{-4} \mathrm{M}$ ouabain for $30 \mathrm{~min}$. Then all samples were dried in oven during $24 \mathrm{~h}$ at $105^{\circ} \mathrm{C}$. In vitro experiments brain tissue samples were pre-incubated in $10 \mathrm{ml}$ cold $\left(7^{\circ} \mathrm{C}\right.$ ) PS containing $1.8 \mu 1^{45} \mathrm{Ca}^{2+}$ (as a control) for $30 \mathrm{~min}$ and transferred into PS containing different concentrations of ouabain. Then they were dried in oven at $105^{\circ} \mathrm{C}$ for $24 \mathrm{~h}$. The quantity of ${ }^{45} \mathrm{Ca}^{2+}$ uptake by brain slices was expressed by $\mathrm{cpm} / \mathrm{mg} \mathrm{d}$. w.

For measurement of ${ }^{45} \mathrm{Ca}^{2+}$ efflux 240 brain slices for each young and old rats were pre-incubated for $60 \mathrm{~min}$ in $\mathrm{K}^{+}$-free (containing $50 \% \mathrm{NaCl})$ cold $\left(7^{\circ} \mathrm{C}\right)$ PS where ${ }^{45} \mathrm{Ca}^{2+}$ was added $\left(1.8 \mu 1{ }^{45} \mathrm{Ca}^{2+}\right.$ for $10 \mathrm{ml}$ PS) in order to enrich tissues by ${ }^{45} \mathrm{Ca}^{2+}$. Then ${ }^{45} \mathrm{Ca}^{2+}$. enriched samples were washed three times (in $\mathrm{K}^{+}$-free solution) for 10,5 and 5 min for removing extracellular ${ }^{45} \mathrm{Ca}^{2+}$. After the washout of 40 brain slices of young and old rats were placed in oven for $24 \mathrm{~h}$ at $105^{\circ} \mathrm{C}$ for detecting initial contents of ${ }^{45} \mathrm{Ca}^{2+}$. The rest 200 brain slices of young and old rats were divided into 5 groups, (40 slices in each group) and were incubated for $30 \mathrm{~min}$ in ouabain-free PS and $10^{-11}, 10^{-10}, 10^{-9}$ and $10^{-4} \mathrm{M}$ ouabain containing PS. After this procedure they were dried in oven at $105^{\circ} \mathrm{C}$ for $24 \mathrm{~h}$.

${ }^{45} \mathrm{Ca}^{2+}$ content was measured by the same way as $\left[{ }^{3} \mathrm{H}\right]$-ouabain receptors as is described above. Taking the number of counts per minute (cpm) remaining in the samples at the end of experiments and adding back the cpm in each sample, the total radioactivity in tissue samples at the beginning of each collecting period was obtained. Then the rate constant of ${ }^{45} \mathrm{Ca}^{2+}$ efflux was calculated.

\subsection{Statistic analysis}

Microsoft Excel and Sigma-Plot (Version 8.02A, NY, and USA) were used for data analysis. Significance in comparison with the control group was calculated with Student's paired $\mathrm{t}$ - test with the following symbols $(* \mathrm{P}<0.05 ; * * \mathrm{P}<0.01 ; * * * \mathrm{P}<0.001)$.

\section{Results}

\subsection{Ouabain effect on brain cortex tissue hydration}

As the major part $(80 \%)$ of brain tissue consists of intracellular water [38], in present work tissue hydration serves as a parameter for estimation of intracellular water content in brain tissue.

It is known that inhibition of ion-transporting function of electrogenic $\mathrm{Na}^{+} / \mathrm{K}^{+}$-pump leads to neuronal hydration [17], [18], [19]. As the dysfunction of $\mathrm{Na}^{+} / \mathrm{K}^{+}$-pump is a consequence of aging, it is predicted that pump inhibition could cause more pronounced brain cortex tissue hydration in young animals than in old ones. However, the data presented in Fig. 1A indicate the opposite effect Intraperitoneal injection with $10^{-4} \mathrm{M}$ ouabain led to the increase of brain cortex tissue hydration which was more pronounced in brain tissues of old (16\%) rats than those of young (7\%) ones.
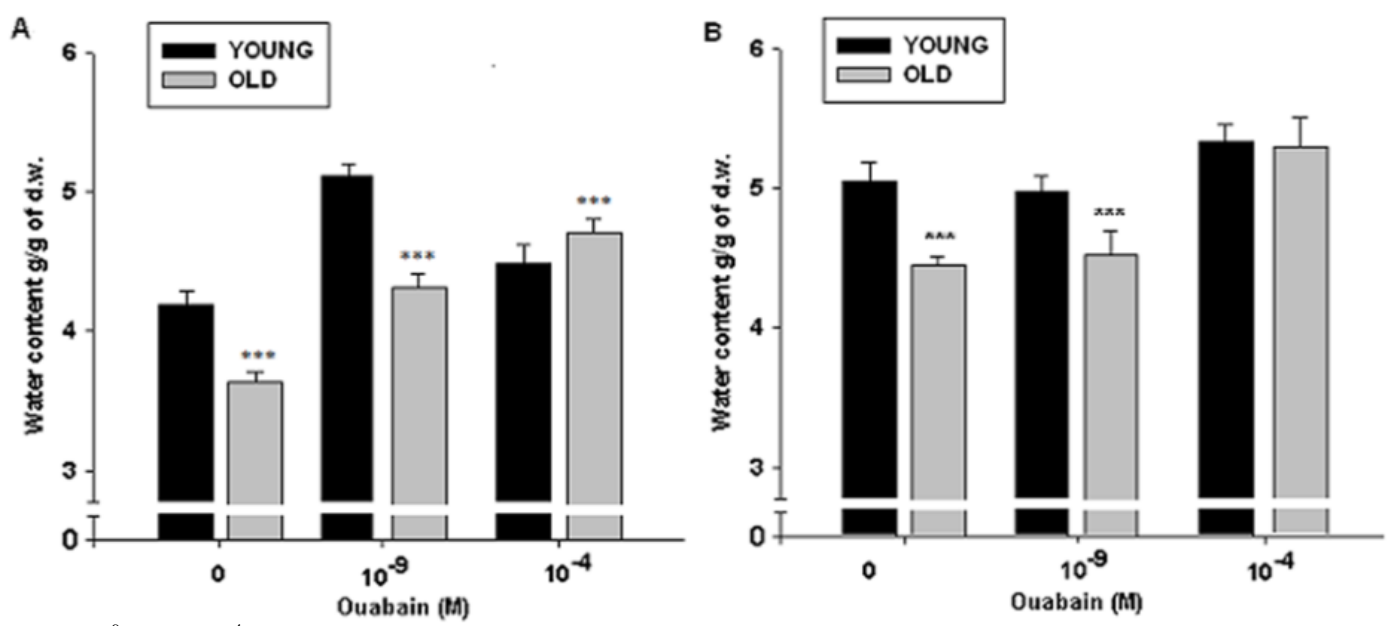

Fig. 1: The Effect of $10^{-9} \mathrm{M}$ and $10^{-4} \mathrm{M}$ Ouabain on Water Content (Grams of Wet Weight/Dry Weight) in Brain Cortex Tissues of Young and Old Rats in Vivo (A) and in Vitro (B) Experiments. Water Content of Brain Slices in Vivo Experiments was Determined after 30 Min of Intraperitoneal Injection Of Ouabain-Free and Ouabain-Containing $\left(10^{-9} \mathrm{M}\right.$ and $\left.10^{-4} \mathrm{M}\right)$ PS. Water Content of Brain Slices in Vitro Experiments was Determined after $30 \mathrm{Min}$ of Incubation of Brain Cortex Slices in Ouabain-Free and Ouabain-Containing $\left(10^{-9} \mathrm{M}\right.$ and $\left.10^{-4} \mathrm{M}\right)$ PS. Black and White Bars Indicate the Water Content of Brain Cortex Tissues of Young and Old Rats, Respectively. Under Each Pair of Columns Corresponding Ouabain Concentrations are noted. Data of Each Pair of Bars are compared with Each other. Error Bars Indicate the Standard Error of the Mean ( \pm SEM) of 120 Samples (40 X 3) for Three Independent Experiments. The Symbol (***) Indicates $\mathrm{P}<0.001$.

In order to elucidate the role of initial metabolic state of brain tissue in determination of age-dependent increasing effect of 10 ${ }^{4} \mathrm{M}$ ouabain on tissue hydration, the same protocol of experiments was also performed in vitro conditions where brain tissue samples were incubated in cold $\left(7^{\circ} \mathrm{C}\right)$ PS. As can be seen in Fig. $1 \mathrm{~B}$, the depression of metabolic activity of tissue incubated in cold PS led to the increase of tissue hydration in both young (20\%) and old $(21 \%)$ animals compared with those of in vivo experiments (Fig. 1A). However, $10^{-4} \mathrm{M}$ ouabain-produced additional tissue hydration lost its age-dependent character (Fig. 1B).

By our early work we have shown that in snail neurons $>10^{-7} \mathrm{M}$ ouabain concentrations have inactivation effect on $\mathrm{Na}^{+} / \mathrm{K}^{+}$-pump, while $<10^{-7} \mathrm{M}$ ouabain has activation effect on $\mathrm{Na}^{+}$efflux [8]. As can be seen in Fig. 1, in young animals intraperitoneal injection of $10^{-9} \mathrm{M}$ ouabain (agonist for $\alpha_{3}$ isoform) led to more pronounced increase of brain cortex tissue hydration $(23.5 \%)$ than $10^{-4} \mathrm{M}$ $(13.5 \%)$ ouabain-induced inactivation of $\mathrm{Na}^{+} / \mathrm{K}^{+}$-pump. Moreover, the differences between the effects of $10^{-4} \mathrm{M}$ and $10^{-9} \mathrm{M}$ ouabain on tissue hydration had age-dependent decreasing character.
The facts that the increase of $\left[\mathrm{Ca}^{2+}\right]_{i}$ serves as one of the essential hallmarks for aging [39] and $\left[\mathrm{Ca}^{2+}\right]_{\mathrm{i}}$ has a central role in intracellular signaling system of neurons [40], [41] allow us to suggest the increase of $\left[\mathrm{Ca}^{2+}\right]_{\mathrm{i}}$ as a potential candidate through which the intracellular signaling systems controlling age-dependent neuronal hydration can be realized. Therefore, to check this suggestion in next series of experiments age-dependent effects of different doses of ouabain on ${ }^{45} \mathrm{Ca}^{2+}$ uptake and efflux in brain tissue were studied.

\subsection{Ouabain effect on ${ }^{45} \mathrm{Ca}^{2+}$ uptake}

In Fig. 2A, data of experiments on ${ }^{45} \mathrm{Ca}^{2+}$ uptake by tissue of brain cortex of young and old rats after intraperitoneal injections of ${ }^{45} \mathrm{Ca}^{2+}$-containing PS (control), PS containing $\left({ }^{45} \mathrm{Ca}^{2+}\right)+10^{-9} \mathrm{M}$ and PS containing $\left({ }^{45} \mathrm{Ca}^{2+}\right)+10^{-4} \mathrm{M}$ ouabain are presented. In Fig. $2 \mathrm{~B}$, data of experiments on ${ }^{45} \mathrm{Ca}^{2+}$ uptake by brain slices incubated in cold $\left(7^{\circ} \mathrm{C}\right)$ PS containing ${ }^{45} \mathrm{Ca}^{2+}$, PS containing $\left({ }^{45} \mathrm{Ca}^{2+}\right)+10^{-9}$ and PS containing $\left({ }^{45} \mathrm{Ca}^{2+}\right)+10^{-4} \mathrm{M}$ ouabain mediums are presented. 
A

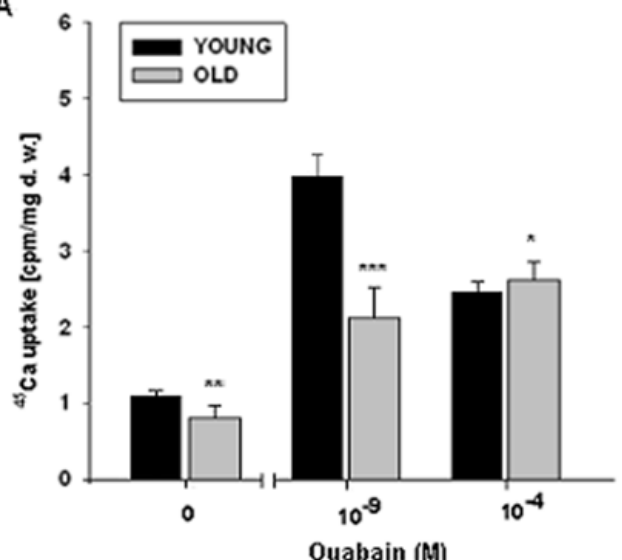

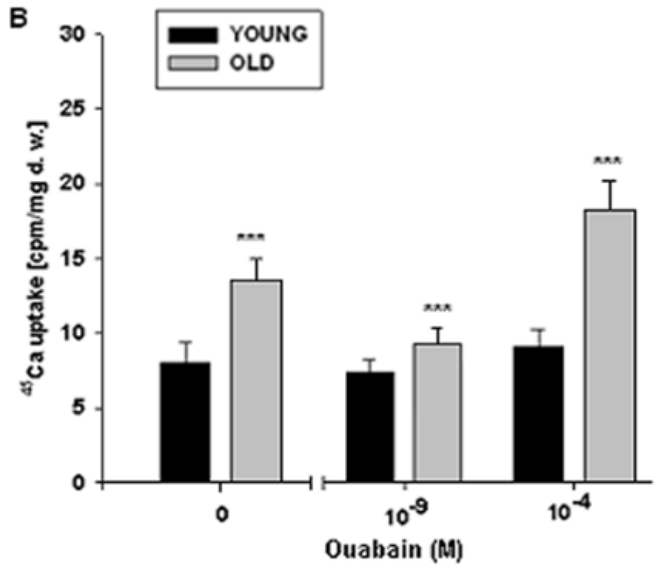

Fig. 2: ${ }^{45} \mathrm{Ca}^{2+}$ Uptake (Cpm/Mg Dry Weight) in Brain Cortex Tissues of Young and Old Animals. $(\mathrm{A}){ }^{45} \mathrm{Ca}^{2+}$ Uptake in Vivo Experiments Was Determined After $30 \mathrm{Min}$ of Intraperitoneal Injection of Ouabain-Free and Ouabain-Containing $\left(10^{-9} \mathrm{M}\right.$ and $\left.10^{-4} \mathrm{M}\right)$ PS. (B) Determination of ${ }^{45} \mathrm{Ca}^{2+} \mathrm{Uptake}$ in Vitro Experiments Was Performed in the Same Conditions. The Size of Columns Indicates ${ }^{45} \mathrm{Ca}^{2+}$ Uptake by Tissue Expressed in Cpm/Mg Dry Weight. Under Each Pair of Columns Corresponding Ouabain Concentrations are noted. Error Bars Indicate the Standard Error of the Mean \pm SEM of 120 Samples (40x3) for Three Independent Experiments. The Symbols $(*),(* *)$ and $(* *)$ Indicate $\mathrm{P}<0.05, \mathrm{P}<0.01$ and $\mathrm{P}<0.001$, Respectively.

As can be seen in Fig. 2A, in vivo experiments, the initial level (control) of ${ }^{45} \mathrm{Ca}^{2+}$ uptake by brain tissue of young rats was $27 \%$ higher than in old ones. The injection with $10^{-9} \mathrm{M}$ and $10^{-4} \mathrm{M}$ ouabain led to the increase of ${ }^{45} \mathrm{Ca}^{2+}$ uptake both in young and old animals compared with control. However, $10^{-9} \mathrm{M}$ ouabain-induced stimulation effect on ${ }^{45} \mathrm{Ca}^{2+}$ uptake in young animals was significantly higher $(259 \%)$ than in old ones $(162 \%)$, while in case of poisoning by $10^{-4} \mathrm{M}$ ouabain, ${ }^{45} \mathrm{Ca}^{2+}$ uptake was higher in old animals $(250 \%$.) than in young ones $(127 \%)$.

Unlike in vivo experiments, in vitro experiments, when brain slices were incubated in cold PS (30 min), the initial level of ${ }^{45} \mathrm{Ca}^{2+}$ uptake (control) was by $92 \%$ higher in old animals than in young ones (Fig. 2B). $10^{-9} \mathrm{M}$ and $10^{-4} \mathrm{M}$ ouabain concentrations also had age-dependent increasing effect on ${ }^{45} \mathrm{Ca}^{2+}$ uptake by brain samples. It is worth to note that the reciprocal effects of $10^{-9} \mathrm{M}$ and $10^{-4} \mathrm{M}$ ouabain on ${ }^{45} \mathrm{Ca}^{2+}$ uptake by tissue were more pronounced in old animals than in young ones (Fig. 2B). Furthermore, in $10^{-9} \mathrm{M}$ ouabain-containing PS, ${ }^{45} \mathrm{Ca}^{2+}$ uptake by tissue had more pronounced age-dependent depressing character than ${ }^{45} \mathrm{Ca}^{2+}$ uptake by brain samples bathing in ouabain-free and $10^{-4} \mathrm{M}$ ouabain-containing PS. However, this depressing effect was more pronounced in old animals than in young ones.

$\mathrm{Ca}^{2+}$ uptake by cells is realized by agonist- and potential-activated ionic channels and $\mathrm{Na}^{+} / \mathrm{Ca}^{2+}$ exchange in reverse mode ( $\mathrm{R}$ $\mathrm{Na}^{+} / \mathrm{Ca}^{2+}$ exchange). It is known that the decrease of extracellular $\mathrm{Na}^{+}\left(\left[\mathrm{Na}^{+}\right]_{0}\right)$ leads to stimulation of $\mathrm{R} \mathrm{Na}^{+} / \mathrm{Ca}^{2+}$ exchange $[42,43]$. Therefore, to check the contribution of $\mathrm{R} \mathrm{Na}^{+} / \mathrm{Ca}^{2+}$ exchange in
${ }^{45} \mathrm{Ca}^{2+}$ uptake as well as in cell hydration in norm and upon the effect of ouabain, age-dependent effects of different doses of ouabain on ${ }^{45} \mathrm{Ca}^{2+}$ uptake, tissue hydration and $\left[{ }^{3} \mathrm{H}\right]$-ouabain binding with cell membranes in both PS containing $100 \%$ (normal) and $50 \%\left[\mathrm{Na}^{+}\right]_{\mathrm{o}}$ and in vitro experiments were studied.

As can be seen in Fig. 3, 50\% $\left[\mathrm{Na}^{+}\right]_{\mathrm{o}}$ PS led to activation of $\mathrm{R}$ $\mathrm{Na}^{+} / \mathrm{Ca}^{2+}$ exchange in brain tissues (Fig. 3A), which was accompanied by tissue dehydration (Fig. 3B). Moreover, $50 \%\left[\mathrm{Na}^{+}\right]_{\mathrm{o}} \mathrm{PS}$ had stronger activation effect on $\mathrm{R} \mathrm{Na}^{+} / \mathrm{Ca}^{2+}$ exchange in brain tissue of old animals compared with young ones.

The activation effect of $10^{-9} \mathrm{M}$ ouabain on $\mathrm{R} \mathrm{Na}^{+} / \mathrm{Ca}^{2+}$ exchange in brain tissue slices of young animals which was absent in ouabainfree PS, appeared at $50 \%\left[\mathrm{Na}^{+}\right]_{0} \mathrm{PS}$ (Fig. 3C), like in vivo experiments (Fig. 2A). Furthermore, $10^{-4} \mathrm{M}$ ouabain effect on $\mathrm{R}$ $\mathrm{Na}^{+} / \mathrm{Ca}^{2+}$ exchange was insensitive to $50 \%\left[\mathrm{Na}^{+}\right]_{\mathrm{o}}$ PS. In old animals $10^{-9} \mathrm{M}$ ouabain had inhibition, while $10^{-4} \mathrm{M}$ ouabain activation effect on $\mathrm{R} \mathrm{Na}^{+} / \mathrm{Ca}^{2+}$ exchange (Fig. 3D) at $50 \%\left[\mathrm{Na}^{+}\right]_{0}$ PS

Previously we have shown that dose-dependent $\left[{ }^{3} \mathrm{H}\right]$-ouabain binding with $a_{3}$ isoform has down-regulation character in brain tissue of young animals which is absent in old ones because of age-dependent increase of $\left[\mathrm{Ca}^{2+}\right]_{\mathrm{i}}[30]$. The comparative study of dose-dependent $\left[{ }^{3} \mathrm{H}\right]$-ouabain binding with cell membrane and its effect on tissue hydration in cortex samples bathing in $100 \%$ and $50 \%\left[\mathrm{Na}^{+}\right]_{\mathrm{o}}$ PS both in young and old rats brings us to the same conclusion (Fig. 4).
A

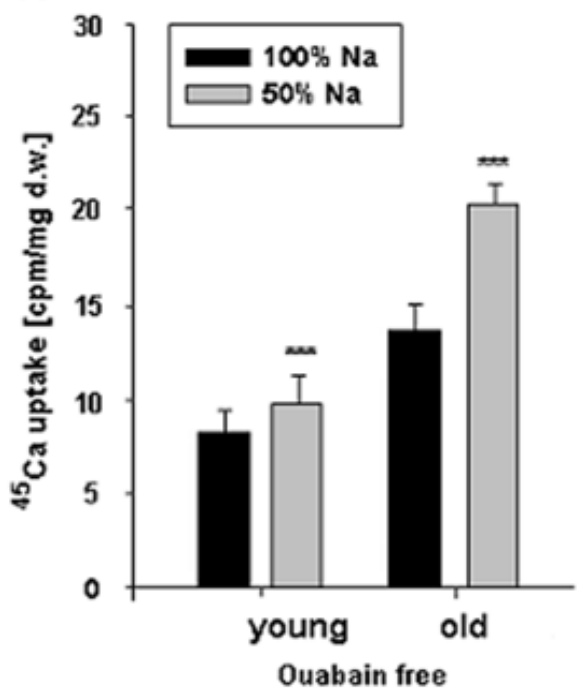

B

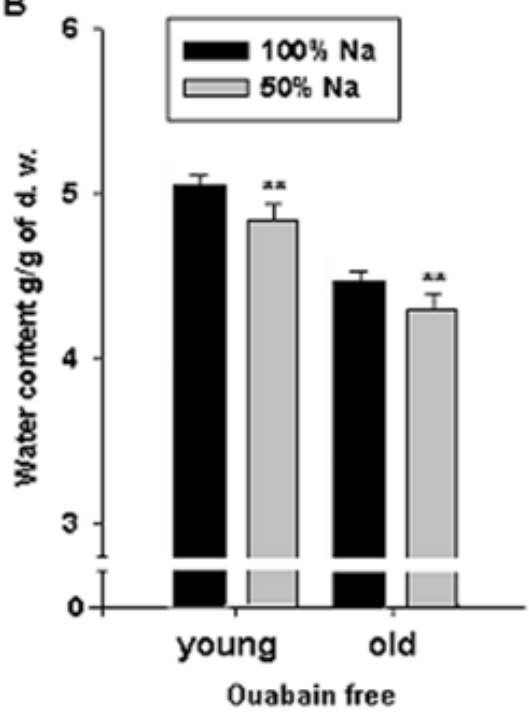



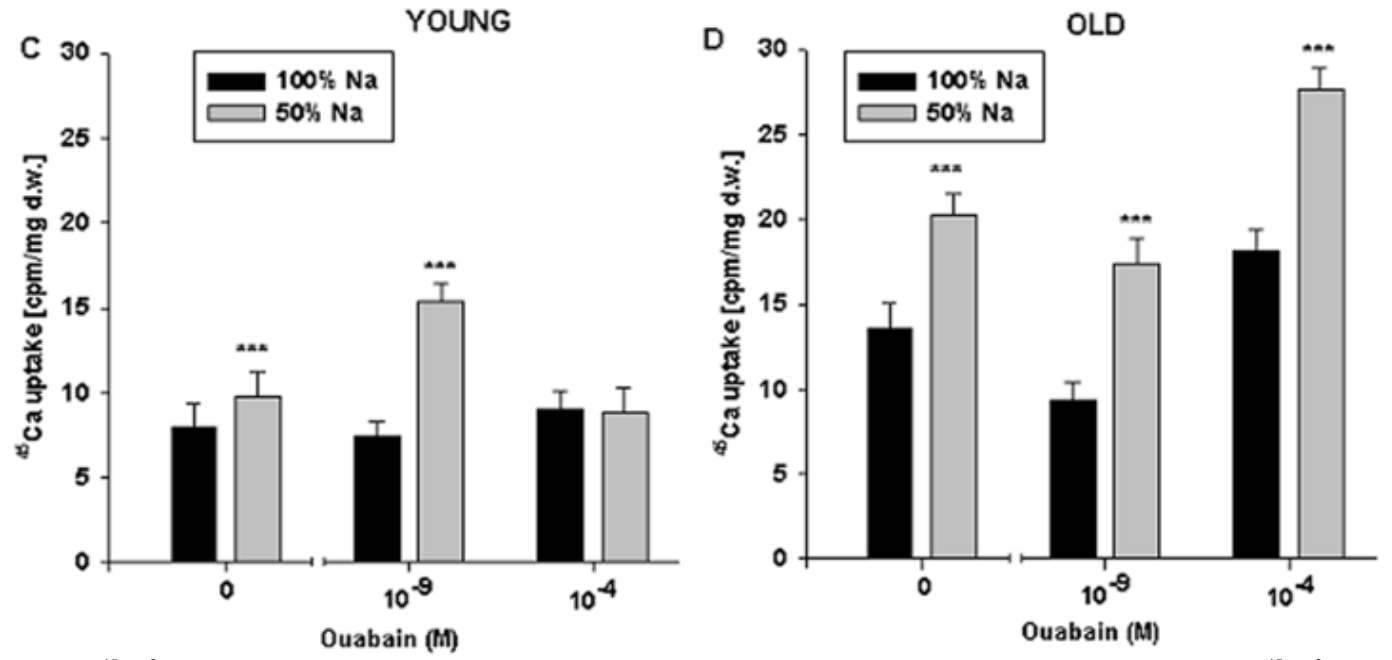

Fig. 3: Age-Dependent ${ }^{45} \mathrm{Ca}^{2+}$ Uptake and Water Content in Brain Cortex Tissues Incubated in $100 \%$ and $50 \%$ [Na $]_{\mathrm{O}} \mathrm{PS}$. (A) ${ }^{45} \mathrm{Ca}^{2+} \mathrm{Content}$ and $\mathrm{Water}$ Content (B) in Brain Tissue Samples of Young and Old Animals Incubated in $100 \%$ and $50 \%\left[\mathrm{Na}^{+}\right]_{\mathrm{O}}$ PS Containing $11.2 \mathrm{Mci} / \mathrm{L}^{45} \mathrm{Ca}^{2+}$. ${ }^{45} \mathrm{Ca}{ }^{2+} \mathrm{Content}$ in Brain Tissue Samples of Young (C) and Old (D) Animals Incubated in Ouabain-Free and Ouabain-Containing (10 $\left.{ }^{-9} \mathrm{M}, 10^{-4} \mathrm{M}\right) 100 \%$ and $50 \%\left[\mathrm{Na}^{+}\right]_{\mathrm{O}} \mathrm{PS}$. Data on Tissue Hydration and ${ }^{45} \mathrm{Ca}^{2+}$ Uptake by Tissue at $100 \%\left[\mathrm{Na}^{+}\right]_{\mathrm{O}}$ PS Were Taken from the Data Presented in Fig. 1 and Fig. 2 , Respectively. Error Bars Indicate Standard Error of the Mean $( \pm$ SEM) for Three Independent Experiments. The Symbols $(* *)$ and $(* * *)$ Indicate P<0.01 and P<0.001, Respectively. For the Study of the Effect of $50 \%\left[\mathrm{Na}^{+}\right]_{\mathrm{O}}$ PS on Tissue Hydration and ${ }^{45} \mathrm{Ca}^{2+}$ Uptake 45 Young and 45 Old Rats were Used.

YOUNG
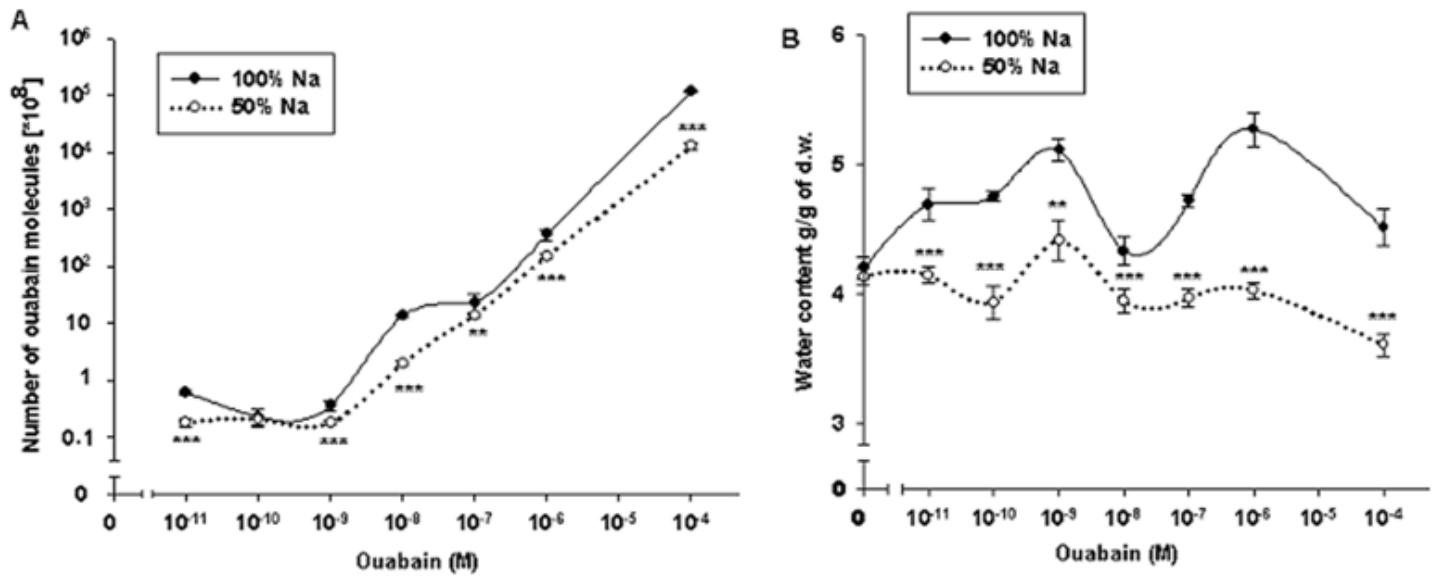

OLD
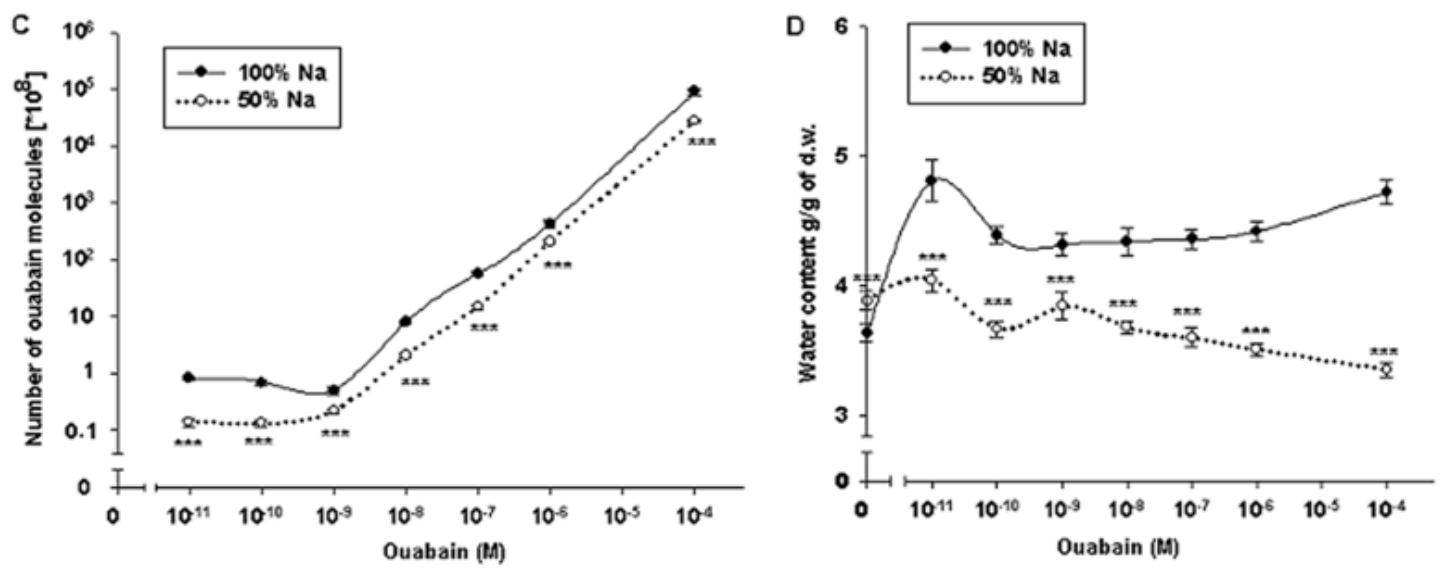

Fig. 4: Dose-Dependent $\left[{ }^{3} \mathrm{H}\right]$-Ouabain Binding with Cell Membrane and Its Effect on Water Content in Brain Tissue of Young (A) and Old (C) Animals after 30 Min of Intraperitoneal Injection of $100 \%$ (Continuous Lines) and 50\% (Dash Lines) [Na $\left.{ }^{+}\right]_{\mathrm{O}}$ PS (0.2 Ml/G of Animal Weight). Ordinates are Logarithmic and Define the Number of Ouabain Molecules $\left[\mathrm{X}_{10}{ }^{8}\right]$ for G of D.W. of Tissues; Abscissas Indicate $\left[{ }^{3} \mathrm{H}\right]-\mathrm{Ouabain}$ Concentrations in M. Each Point of Curve Is the Mean \pm SD for Three Independent Experiments (N=120). Dose-Dependent Ouabain Effect on Water Content (G/G of D.W.) of Brain Cortex Samples of Young (B) and Old (D) Rats Injected with 100\% (Continuous Lines) and 50\% (Dash Lines) [Na $\left.{ }^{+}\right]_{0}$ PS. Ordinates Indicate Mean Value of Water Content in Young (B) and Old (D) Animals; Abscissas Indicate $\left[{ }^{3} \mathrm{H}\right]$-Ouabain Concentrations in M. Error Bars Indicate the Standard Error of the Mean $( \pm$ SEM) for Three Independent Experiments $(\mathrm{N}=120)$. The Symbols $(* *)$ and $(* * *)$ Indicate $\mathrm{P}<0.01$ and $\mathrm{P}<0.001$, Respectively. 105 Young and 105 Old Rats have Been Used in These Series of Experiments. 
As can be seen in Fig. 4, 50\% $\left[\mathrm{Na}^{+}\right]_{\mathrm{o}}$ PS had strong depressing effect on ouabain binding with cell membrane in brain tissues of both young and old animals (Fig. 4, A and C). It is interesting to note that in young animals (Fig. 4A) the depressing effect of 50\% $\left[\mathrm{Na}^{+}\right]_{\mathrm{o}}$ PS on dose-dependent down-regulation of $\left[{ }^{3} \mathrm{H}\right]$-ouabain binding with $\alpha_{3}$ receptors was similar to aging effect on it (Fig. $4 \mathrm{C})$. However, the depressing effect of $50 \%\left[\mathrm{Na}^{+}\right]_{\mathrm{o}}$ PS on $\left[{ }^{3} \mathrm{H}\right]-$ ouabain binding with $\alpha_{3}$ receptors in brain tissue of old animals was more pronounced than in brain tissues of young ones.

The curves of dose-dependent ouabain effect on brain tissue hydration of young animals consisted of 6 components, 3 of which were located in zones of $\alpha_{3}$ receptors (Fig. 4B), whereas, kinetic curve of dose-dependent $\left[{ }^{3} \mathrm{H}\right]$-ouabain binding with cell membrane in vivo experiments consisted of three family of receptors having different affinities [31]. All concentrations of ouabain at $50 \%\left[\mathrm{Na}^{+}\right]_{\mathrm{o}}$ PS had dehydration effect on brain tissue and their dose-dependent curve in young animals at concentrations of $10^{-10}$ $10^{-4} \mathrm{M}$ ouabain had parallel character at both $100 \%$ and $50 \%$ $\left[\mathrm{Na}^{+}\right]_{\mathrm{o}}$ PS. However, in case of $<10^{-10} \mathrm{M}$ ouabain, dose-dependent curves had opposite directions (Fig. 4B); at $100 \%\left[\mathrm{Na}^{+}\right]_{0}$ PS it had dose-dependent hydration, while at $50 \%\left[\mathrm{Na}^{+}\right]_{\mathrm{o}} \mathrm{PS}$ dose-dependent dehydration character (Fig. 4). In tissues of old rats in both $100 \%$ and $50 \%\left[\mathrm{Na}^{+}\right]_{\mathrm{o}} \mathrm{PS}$ these curves had smoother character (Fig. 4D). Age-dependent differences between the effects of low $\left(<10^{-9} \mathrm{M}\right)$ and high concentrations $\left(>10^{-4} \mathrm{M}\right)$ of ouabain on tissue hydration and $\mathrm{R} \mathrm{Na}^{+} / \mathrm{Ca}^{2+}$ exchange allow us to suggest that there are different mechanisms involved in this process. To check this suggestion dose-dependent ouabain effect on ${ }^{45} \mathrm{Ca}^{2+}$ efflux $\left(\mathrm{F} \mathrm{Na}^{+} / \mathrm{Ca}^{2+}\right.$ exchange) from the cells of brain tissue was studied in the next series of experiments.

\subsection{Ouabain effect on $\mathrm{Ca}^{2+}$ efflux from the cells}

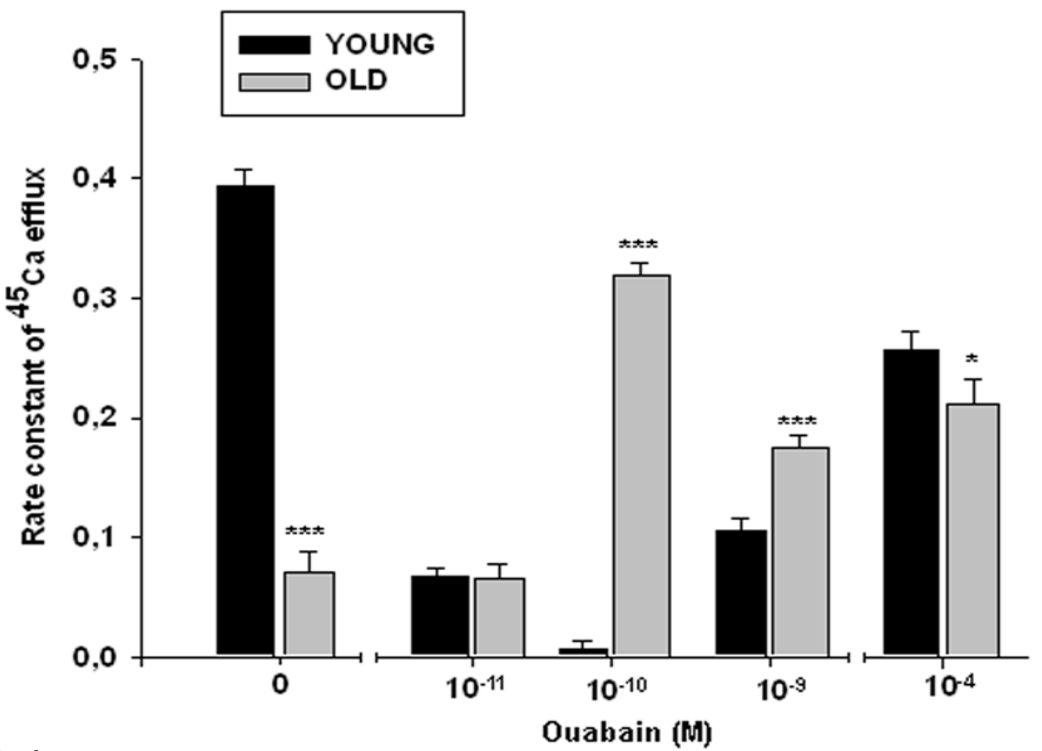

Fig. 5: The Rate Constant of ${ }^{45} \mathrm{Ca}^{2+}$ Efflux from Brain Cortex Tissue Samples of Young and Old Animals in Ouabain-Free and Ouabain-Containing (10 ${ }^{-11}$, $\left.10^{-10}, 10^{-9}, 10^{-4} \mathrm{M}\right)$ PS. Brain Slices were Preliminary Enriched by ${ }^{45} \mathrm{Ca}^{2+}$ by Incubating them for $60 \mathrm{Min}$ in $\mathrm{K}^{+}$-Free (Containing 50\% Nacl) Cold ( $7^{\circ} \mathrm{c}$ ) PS (Containing1.8 Ml $\left.{ }^{45} \mathrm{Ca}^{2+}\right)$. Error Bars Indicate the Standard Error of the Mean $( \pm \mathrm{SEM})$ for Three Independent Experiments $(\mathrm{N}=120)$. The Symbols $(*)$, and (***) Indicate $\mathrm{P}<0.05$ and $\mathrm{P}<0.001$, Respectively. 75 Young and 75 Old Rats were used in these Series of Experiments.

\section{Discussion}

Traditionally, metabolic regulation of cell hydration is explained either by the changes of transporting function of membrane [46], [47], [48], [21], [22] or by the changes of sorption properties of cytoplasm [49], [50], [51]. However, there is a lack of adequate consideration to fundamental role of intracellular signaling systems controlling the release of endogenous $\mathrm{H}_{2} \mathrm{O}$ in regulation of cell hydration. It is known that $42 \mathrm{H}_{2} \mathrm{O}$ molecules are formed in cytoplasm during oxidation of one molecule glucose [26]. As the
In order to estimate the role of ${ }^{45} \mathrm{Ca}^{2+}$ efflux in observed agedependent changes of ouabain effects on the rate of $\mathrm{R} \mathrm{Na}^{+} / \mathrm{Ca}^{2+}$ exchange in brain tissue, the comparative study of $10^{-9} \mathrm{M}$ and $10^{-}$ ${ }^{4} \mathrm{M}$ ouabain effects on ${ }^{45} \mathrm{Ca}^{2+}$ efflux from the preliminary ${ }^{45} \mathrm{Ca}^{2+}$. enriched brain samples were studied.

$\left[\mathrm{Ca}^{2+}\right]_{\mathrm{i}}$ can be decreased by removing $\mathrm{Ca}^{2+}$ from the cytosol by various mechanisms; a) by $\mathrm{Ca}^{2+}$-pumps in membrane of endoplasmatic reticulum (ER) and in PM pushing $\mathrm{Ca}^{2+}$ into ER or outside the cell, respectively, b) by $\mathrm{Na}^{+} / \mathrm{Ca}^{2+}$ exchange in forward mode $\left(\mathrm{F} \mathrm{Na}^{+} / \mathrm{Ca}^{2+}\right.$ exchange) extruding cytosolic $\mathrm{Ca}^{2+}$ in exchange for extracellular $\mathrm{Na}^{+} . \mathrm{Ca}^{2+}$-pump in cell membrane controls the rest $\mathrm{Ca}^{2+}$ concentrations because of their high-affinity/lowcapacity transport properties, whereas, $\mathrm{Na}^{+} / \mathrm{Ca}^{2+}$ exchangers display low-affinity/high-capacity transport properties [44]. Therefore, in case of high $\left[\mathrm{Ca}^{2+}\right]_{i}$, when $\mathrm{Ca}^{2+}$-pumps in ER and PM are in inhibited state, the net $\mathrm{Ca}^{2+}$ efflux is mainly determined by $\mathrm{F}$ $\mathrm{Na}^{+} / \mathrm{Ca}^{2+}$ exchange [45].

As can be seen in Fig. 5, the rate of ${ }^{45} \mathrm{Ca}^{2+}$ efflux from the brain samples of young rats was significantly higher than in old ones. Ouabain had inactivation effect on the rate of ${ }^{45} \mathrm{Ca}^{2+}$ efflux from the brain samples of young rats, while in old animals ouabain had activation effect on it. It is worth to note that the inactivation effect of ouabain on ${ }^{45} \mathrm{Ca}^{2+}$ efflux from brain samples of young rats appeared at $<10^{-11} \mathrm{M}$ ouabain and was lessened by the increase of ouabain concentrations. However, activation effect of ouabain on ${ }^{45} \mathrm{Ca}^{2+}$ efflux from brain tissue samples in old animals was observed at $>10^{-11} \mathrm{M}$ ouabain. Furthermore, inactivation effect of $\mathrm{nM}$ ouabain on ${ }^{45} \mathrm{Ca}^{2+}$ efflux in young and activation effect on ${ }^{45} \mathrm{Ca}^{2+}$ efflux in old rats were significantly pronounced at $10^{-10} \mathrm{M}$ concentration of ouabain (Fig. 4 and Fig. 5). 
lular oxidative processes. This suggestion is supported by the data that initial level of tissue hydration of young and old rats was higher in vitro experiments (Fig. 1B) than in vivo ones (Fig. 1A). It is obvious that cell membrane permeability in brain tissue samples was higher in vitro experiments than in vivo ones which predicted the increase of ATP utilization for controlling intracellular homeostasis. The data presented in Figure 1A clearly indicate that age-dependent elevation effect of $10^{-4} \mathrm{M}$ ouabain on cortex tissue hydration cannot be explained only by $10^{-4} \mathrm{M}$ ouabain-induced inhibition of ion-transporting function of $\mathrm{Na}^{+} / \mathrm{K}^{+}$-ATPase in plasma membrane (PM). Therefore, cell hydration in response of the increase of cell membrane permeability can be considered as a result of the uptake of osmotic particles by cell as well as the increase of endogenous $\mathrm{H}_{2} \mathrm{O}$. The suggestion that cell hydration depends on its metabolic activity is also supported by the fact that in vitro experiments age-dependent tissue hydration disappeared at $10^{-4} \mathrm{M}$ ouabain-induced inhibition of $\mathrm{Na}^{+} / \mathrm{K}^{+}$pump activity (Fig. 1B) which was observed in vivo experiments (Fig. 1A).

$\mathrm{Na}^{+} / \mathrm{K}^{+}$pump inhibition-induced cell swelling [55], [17], [18], [19], [22] has been traditionally explained by the depression of its iontransporting function in membrane. From this point of view as transporting function of $\mathrm{Na}^{+} / \mathrm{K}^{+}$-pump is depressed by aging, it is predicted that $10^{-4} \mathrm{M}$ ouabain-induced $\mathrm{Na}^{+} / \mathrm{K}^{+}$-pump inhibition [56] could have more pronounced effect on cell hydration in brain of young animals than in brain of old ones. However, in present work the opposite effect was observed which could serve as strong evidence that $10^{-4} \mathrm{M}$ ouabain, besides inhibition effect on $\mathrm{Na}^{+} / \mathrm{K}^{+}$pump, has also depressing effect on oxidation-induced release of water molecules in cytoplasm which has age-dependent weakening character (Fig. 1). At present, it is well established that among three isoforms of $\mathrm{Na}^{+} / \mathrm{K}^{+}$-ATPase, $\alpha_{1}$ (fully) and $\alpha_{2}$ (partly) have ion-transporting functions, while $\alpha_{3}$ isoform, activated by $\leq 10^{-9} \mathrm{M}$ ouabain, performs only intracellular signaling function [45], [57], [58]. Although the crucial role of $\mathrm{Na}^{+} / \mathrm{K}^{+}$-pump in regulation of neuronal hydration is well established [17], [18], [13], [8], [10], [21], [22], the individual roles of different isoforms of $\mathrm{Na}^{+} / \mathrm{K}^{+}$ ATPase (working molecules of pump) in this process is not elucidated yet.

It is known that brain tissue consists of neuronal and glial cells. Therefore, brain tissue hydration is a sum of neuronal and glial cells hydration. As it was mentioned above, $\mathrm{Na}^{+} / \mathrm{K}^{+}$-ATPase in cell membrane has ion-transporting and intracellular signaling functions. Moreover, $\alpha_{3}$ isoform of $\mathrm{Na}^{+} / \mathrm{K}^{+}$-ATPase which is localized only in neurons has only signaling function. Whereas, $\alpha_{1}$ and $\alpha_{2}$ are localized in glial cells and have transporting and signaling functions [59], [60], [61], [62], [63]. Therefore, the effect of $<10$ ${ }^{9} \mathrm{M}$ ouabain on brain cortex tissue hydration can be considered as a result of activation of $\mathrm{a}_{3}$ isoform in neuronal membrane.

The fact that in vivo experiments $10^{-9} \mathrm{M}$ ouabain had stronger activation effect on tissue hydration than $10^{-4} \mathrm{M}$ ouabain (Fig. 1A) allows us to suggest that $10^{-9} \mathrm{M}$ ouabain-induced activation of intracellular signaling system brings to activation of endogenous $\mathrm{H}_{2} \mathrm{O}$ in cytoplasm. This suggestion is supported by the data on the disappearance of $10^{-9} \mathrm{M}$ ouabain-induced increase of tissue hydration in vitro experiments, where metabolic activity of tissue was depressed in cold $\left(7^{\circ} \mathrm{C}\right)$ PS, while $10^{-4} \mathrm{M}$ ouabain-induced tissue hydration was increased (Fig. 1B) compared with the hydration of the samples incubated in ouabain-free PS.

The data presented in Figure 2 show that the injection of $10^{-9} \mathrm{M}$ ouabain leads to the increase of ${ }^{45} \mathrm{Ca}^{2+}$ uptake by cells, which has an age-dependent weakening character (Fig. 2 A). The data that the effect of $10^{-9} \mathrm{M}$ ouabain on ${ }^{45} \mathrm{Ca}^{2+}$ uptake is significantly higher than $10^{-4} \mathrm{M}$ ouabain (having strong inhibition effect on $\mathrm{Na}^{+} / \mathrm{K}^{+}$pump) clearly indicate that $10^{-9} \mathrm{M}$ ouabain-induced activation of ${ }^{45} \mathrm{Ca}^{2+}$ uptake cannot be explained by the inhibition of $\mathrm{Na}^{+} / \mathrm{K}^{+}$pump as it is traditionally suggested [42], [45].

It is known that ${ }^{45} \mathrm{Ca}^{2+}$ uptake by cells could be realized by agonist-, potential-activated $\mathrm{Ca}^{2+}$-channels and $\mathrm{R} \mathrm{Na}^{+} / \mathrm{Ca}^{2+}$ exchange in membrane. In our previous study it has been shown that low $\left(<10^{-7} \mathrm{M}\right)$ concentrations of ouabain has no effect on $\mathrm{Na}^{+} / \mathrm{K}^{+}$-pump activity [8], instead it has activation effect on cAMP formation and $\mathrm{R} \mathrm{Na}^{+} / \mathrm{Ca}^{2+}$ exchange [64]. This allows us to suggest that $10^{-9}$ $\mathrm{M}$ ouabain-induced activation of ${ }^{45} \mathrm{Ca}^{2+}$ uptake (Fig. 2, A) is due to the activation of $\mathrm{R} \mathrm{Na}^{+} / \mathrm{Ca}^{2+}$ exchange.

The activation of ${ }^{45} \mathrm{Ca}^{2+}$ uptake by brain tissue samples in vitro experiments can be explained by activation of ionic channels and $\mathrm{R} \mathrm{Na}{ }^{+} / \mathrm{Ca}^{2+}$ exchange. Therefore, the age-dependent elevation effect of ${ }^{45} \mathrm{Ca}^{2+}$ uptake in vitro experiments compared with that of in vivo ones can be explained by the depression of $\left[\mathrm{Ca}^{2+}\right]_{i}$ buffering system in old animals.

As $10^{-4} \mathrm{M}$ ouabain has inhibitory effect on $\mathrm{Na}^{+} / \mathrm{K}^{+}$-pump [56] which leads to membrane depolarization and excitation $[65,66]$, ${ }^{45} \mathrm{Ca}^{2+}$ uptake can be considered as a result of activation of $\mathrm{Ca}^{2+}$ channels and $\mathrm{R} \mathrm{Na}^{+} / \mathrm{Ca}^{2+}$ exchange (Fig. 2). The data that in vivo experiments the activation of ${ }^{45} \mathrm{Ca}^{2+}$ uptake and its agedependent reverse took place at $10^{-4} \mathrm{M}$ ouabain-induced pump inhibition (Fig. 2A), which was more significant than in vitro experiments (Fig. 2B), indicate the crucial role of $\mathrm{Na}^{+} / \mathrm{K}^{+}$-pump in metabolic controlling of $\left[\mathrm{Ca}^{2+}\right]_{\mathrm{i}}$ buffering system in brain cells. As it was noted above, $10^{-9} \mathrm{M}$ ouabain-induced activation of ${ }^{45} \mathrm{Ca}^{2+}$ uptake can be considered as a response of activation of $\alpha_{3}$ isoform having only signaling function [57], [63]. The fact that $10^{-9} \mathrm{M}$ and $10^{-4} \mathrm{M}$ ouabain-induced activation effects on ${ }^{45} \mathrm{Ca}^{2+}$ uptake are realized by different mechanisms is supported by the following experimental data: a) in vivo experiments $10^{-9} \mathrm{M}$ ouabain-induced activation of ${ }^{45} \mathrm{Ca}^{2+}$ uptake in young animals was more pronounced than $10^{-4} \mathrm{M}$ ouabain effect, while $10^{-4} \mathrm{M}$ ouabain stimulation effect in old animals was more pronounced than $10^{-9} \mathrm{M}$ ouabain effect (Fig. 2A), b) in vitro experiments $10^{-9} \mathrm{M}$ ouabain had depressing effect on ${ }^{45} \mathrm{Ca}^{2+}$ uptake by brain tissue samples both in young and old animals compared with ouabain-free PS, while $10^{-}$ ${ }^{4} \mathrm{M}$ ouabain had more pronounced activation effect on ${ }^{45} \mathrm{Ca}^{2+} \mathrm{up}-$ take both in young and old animals than $10^{-9} \mathrm{M}$ ouabain (Fig. 2B). As $\mathrm{Na}^{+} / \mathrm{Ca}^{2+}$ exchanger functions in stoichiometry of $3 \mathrm{Na}^{+}: 1 \mathrm{Ca}^{2+}$ and in case of $\mathrm{K}^{+}$-dependent $\mathrm{Na}^{+} / \mathrm{Ca}^{2+}$ exchanger in stoichiometry of $4 \mathrm{Na}^{+}: 1 \mathrm{Ca}^{2+}+1 \mathrm{~K}^{+}$[64], it was predicted that $10^{-9} \mathrm{M}$ ouabaininduced activation of $\mathrm{R} \mathrm{Na}^{+} / \mathrm{Ca}^{2+}$ exchange should have dehydration effect on brain tissue, however, hydration effect was observed (Fig. 1A). From these data it can be concluded that there is a common metabolic mechanism localized in cytoplasm which is responsible for $10^{-9} \mathrm{M}$ ouabain-induced activation of $\mathrm{R} \mathrm{Na}^{+} / \mathrm{Ca}^{2+}$ exchange and tissue hydration. This metabolic mechanism has age-dependent dysfunctional character (Fig. 2A) and is depressed in vitro experiments when metabolic activity is inhibited (Fig. 2B) This suggestion is confirmed by the data of the comparative study of dose-dependent ouabain effects on cell hydration and $\mathrm{R}$ $\mathrm{Na}^{+} / \mathrm{Ca}^{2}$ exchange in brain tissue samples bathing at $100 \%$ and $50 \%\left[\mathrm{Na}^{+}\right]_{\mathrm{o}} \mathrm{PS}$. As it is known that the decrease of $\left[\mathrm{Na}^{+}\right]_{\mathrm{o}}$ brings to the activation of $\mathrm{R} \mathrm{Na}^{+} / \mathrm{Ca}^{2}$ exchange [42], 50\% $\left[\mathrm{Na}^{+}\right]_{\mathrm{o}} \mathrm{PS}$ induced activation of $\mathrm{R} \mathrm{Na}^{+} / \mathrm{Ca}^{2+}$ exchange was accompanied by cell dehydration (Fig. 3). It is known that there is an agedependent increase of $\left[\mathrm{Ca}^{2+}\right]_{i}[39]$ which predicts the decrease of $50 \%\left[\mathrm{Na}^{+}\right]_{0}$ PS-induced $\mathrm{R} \mathrm{Na}^{+} / \mathrm{Ca}^{2}$ exchange. However, in our experiments the opposite effect was observed. Though the initial level of $\left[\mathrm{Ca}^{2+}\right]_{i}$ in old animals was higher than in young ones, activation effect of $50 \%\left[\mathrm{Na}^{+}\right]_{\mathrm{o}}$ PS on $\mathrm{R} \mathrm{Na}^{+} / \mathrm{Ca}^{2+}$ exchange in old animals was more pronounced than in young ones (Fig. 3A). This can be explained by the existence of an intracellular mechanism controlling $\left[\mathrm{Ca}^{2+}\right]_{\mathrm{i}}$, such as $\mathrm{Ca}^{2+}$-Calmodulin-NO-GMP cascade [67] having activation effect on $\mathrm{F} \mathrm{Na}^{+} / \mathrm{Ca}^{2}$ exchange [68]. This activation effect is stronger in the brain neurons of young rats than in brain neurons of old ones.

The existing modulation effects of $10^{-9} \mathrm{M}$ and $10^{-4} \mathrm{M}$ ouabain on $\mathrm{R}$ $\mathrm{Na}^{+} / \mathrm{Ca}^{2}$ as well as on tissue hydration at both $100 \%$ and $50 \%$ $\left[\mathrm{Na}^{+}\right]_{\mathrm{o}}$ PS (Fig. 3, C and D, Fig. 4, B and D) indicate that the mechanism responsible for $10^{-9} \mathrm{M}$ and $10^{-4} \mathrm{M}$ ouabain-induced increase of cell hydration and rate of $\mathrm{R} \mathrm{Na}^{+} / \mathrm{Ca}^{2+}$ has cytoplasmic origin. This suggestion is supported by the data on $10^{-9} \mathrm{M}$ ouabaininduced reactivation of $\mathrm{R} \mathrm{Na}^{+} / \mathrm{Ca}^{2+}$ exchange in brain tissue of young animals in vivo experiments (Fig. $2 \mathrm{~A}$ ) at $50 \%\left[\mathrm{Na}^{+}\right]_{\mathrm{o}} \mathrm{PS}$ which was reversed in normal PS in vitro experiments (Fig. 3C). Moreover, the effect of $10^{-4} \mathrm{M}$ ouabain on ${ }^{45} \mathrm{Ca}^{2+}$ uptake by tissue 
of old animals bathing in 50\% $\left[\mathrm{Na}^{+}\right]_{\mathrm{o}}$ PS (Fig. 3D) serves as additional evidence supporting the above mentioned suggestion.

Considering the fact that the differences of ionic gradients of $\mathrm{Na}^{+} / \mathrm{Ca}^{2+}$ ions on membrane serves as energy sources for $\mathrm{Na}^{+} / \mathrm{Ca}^{2+}$ exchange, it becomes clear that the activation of cytoplasm absorption of $\left[\mathrm{Ca}^{2+}\right]_{\mathrm{i}}$ will attenuate $50 \%\left[\mathrm{Na}^{+}\right]_{\mathrm{o}}$ PS-induced activation of $\mathrm{R} \mathrm{Na}^{+} / \mathrm{Ca}^{2+}$ exchange. Therefore, $10^{-9} \mathrm{M}$ ouabain-induced reactivation of $\mathrm{R} \mathrm{Na}^{+} / \mathrm{Ca}^{2+}$ at $50 \%\left[\mathrm{Na}^{+}\right]_{0}$ PS in neurons of young animals could be an evidence for $10^{-9} \mathrm{M}$ ouabain-induced activation of $\left[\mathrm{Ca}^{2+}\right]_{i}$ sorption properties of intracellular structures. The fact that the mentioned effect of $10^{-9} \mathrm{M}$ ouabain was depressed in brain neurons of old rats (Fig. 2) can be explained by the agedependent increase of $\left[\mathrm{Ca}^{2+}\right]_{\mathrm{i}}$.

The decrease of $\left[{ }^{3} \mathrm{H}\right]$-ouabain binding with cell membrane at $50 \%$ $\left[\mathrm{Na}^{+}\right]_{0} \mathrm{PS}$ in young and old animals compared with those at $100 \%$ $\left[\mathrm{Na}^{+}\right]_{0} \mathrm{PS}$ is a result of the increase of $\left[\mathrm{Ca}^{2+}\right]_{\mathrm{i}}$ (Fig. 5, A and C). This effect which was more pronounced at $\left[{ }^{3} \mathrm{H}\right]$-ouabain binding with $\mathrm{a}_{3}$ receptors than with $\mathrm{a}_{2}$ and $\mathrm{a}_{1}$ is in harmony with literature data that among mentioned isoforms, $\mathrm{a}_{3}$ has higher affinity to $\mathrm{Ca}^{2+}$ than $\mathrm{a}_{2}$ and $\mathrm{a}_{1}$ [45], [57]. The age-dependent increase of $50 \%$ $\left[\mathrm{Na}^{+}\right]_{0}$-induced inhibition of $\left[{ }^{3} \mathrm{H}\right]$-ouabain binding can be explained by the depression of $\left[\mathrm{Ca}^{2+}\right]_{\mathrm{i}}$ buffering properties of cytoplasm. The data on the comparative study of dose-dependent ouabain effects on tissue hydration of young and old animals in 100\% and $50 \%\left[\mathrm{Na}^{+}\right]_{\mathrm{o}}$ PS bring us to the same conclusion (Fig. 4, B and D). As it was predicted, $50 \%\left[\mathrm{Na}^{+}\right]_{0}$-induced activation of $\mathrm{R}$ $\mathrm{Na}^{+} / \mathrm{Ca}^{2+}$ exchange led to brain tissue dehydration at all ouabain concentrations both in young and old animals. The obtained data demonstrated pronounced age-dependent character of kinetics of ouabain effects on tissue hydration; in young animals these curves consisted of 6 components, whereas, in old animals they had 3 components. Multi-component character of the curves of dosedependent ouabain effects on tissue hydration in young animals which was depressed by aging probably can be explained by the existence of caveolae containing aquaporins [10], especially, by aquaporin-4 (AQP4) which is one of the most abundant molecules in brain tissue [69]. This suggestion cannot be final and needs more detailed investigation.

The suggestion that there is an intracellular signaling system controlling $\left[\mathrm{Ca}^{2+}\right]_{\mathrm{i}}$ absorption properties of cytoplasm which is sensitive to extremely low concentrations of ouabain $\left(\leq 10^{-9} \mathrm{M}\right)$ is supported by the data on dose-dependent effect of ouabain on ${ }^{45} \mathrm{Ca}^{2+}$ efflux from the cortex tissue. As it was noted above, in case of high $\left[\mathrm{Ca}^{2+}\right]_{i}$, when $\mathrm{Ca}^{2+}$-pumps in ER and PM are in inhibited state, the net ${ }^{45} \mathrm{Ca}^{2+}$ efflux is mainly determined by $\mathrm{F} \mathrm{Na}^{+} / \mathrm{Ca}^{2+}$ exchange [43]. Therefore, in vitro experiment when $\left[\mathrm{Ca}^{2+}\right]_{\mathrm{i}}$ is high, ${ }^{45} \mathrm{Ca}^{2+}$ efflux can also be considered as a result of activation of $F$ $\mathrm{Na}^{+} / \mathrm{Ca}^{2+}$ exchange.

In vitro experiments ouabain had inactivation effect on ${ }^{45} \mathrm{Ca}^{2+}$ efflux from brain tissue of young animals, while it had activation effect in old animals (Fig. 5). The threshold of inactivation effect of ouabain on ${ }^{45} \mathrm{Ca}^{2+}$ efflux was much lower $\left(<10^{-11} \mathrm{M}\right)$ in young animals than the threshold $\left(>10^{-10} \mathrm{M}\right)$ of its activation effect on $\mathrm{Ca}^{2+}$ efflux in old ones (Fig. 5). These data clearly indicate that different intracellular signaling systems are responsible for ouabain-induced inhibition and activation of ${ }^{45} \mathrm{Ca}^{2+}$ efflux in young and older animals, respectively. This suggestion is supported by the data that the curves of dose-dependent ouabain effect on ${ }^{45} \mathrm{Ca}^{2+}$ efflux both in young and old animals had opposite character at ouabain concentrations of $<10^{-8} \mathrm{M}\left(\mathrm{a}_{3}\right.$ receptors), while they had parallel character at high concentrations $\left(>10^{-8} \mathrm{M}\right)$. These data are in harmony with literature [63] and our previous data that $\mathrm{a}_{3}$ receptors have more pronounced age-dependent character than $\mathrm{a}_{2}$ and $\mathrm{a}_{1}$ because of its high affinity to $\left[\mathrm{Ca}^{2+}\right]_{\mathrm{i}}[30]$.

The non-monotonic curve of ouabain dose-dependent effect on ${ }^{45} \mathrm{Ca}^{2+}$ efflux in the study of brain tissue hydration of young rats (Fig. 4) can be explained by the existence of caveolae in membrane containing different signaling proteins [10] in result of which the changes of cell volume have a discreet character [8]. The absence of correlation between the rate of $\mathrm{F} \mathrm{Na}^{+} / \mathrm{Ca}^{2+}$ exchange and cell hydration (instead of predicted hydration) one more time wit- nesses that the age-induced cell dehydration cannot be a direct result of depression of $\mathrm{F} \mathrm{Na}^{+} / \mathrm{Ca}^{2+}$ exchange.

Thus, the obtained data allow us to conclude that the dysfunction of intracellular signaling system controlling cell hydration plays a primary role, while ion-transporting cell membrane mechanisms have a secondary role in age-induced brain tissue dehydration.

Based on the data of our previous work that $\mathrm{nM}$ ouabain-induced activation of $\mathrm{R} \mathrm{Na}^{+} / \mathrm{Ca}^{2+}$ exchange is accompanied by the increase of intracellular contents of cAMP [64], which stimulates $\mathrm{Ca}^{2+}$ pump in ER membrane [41], we suggest that the decrease of $\left[\mathrm{Ca}^{2+}\right]_{\mathrm{i}}$ brings to the activation of $\mathrm{R} \mathrm{Na}{ }^{+} / \mathrm{Ca}^{2+}$ exchange (Fig. 2). The $\mathrm{nM}$ ouabain-induced cell hydration can be explained by $\mathrm{Ca}^{2+}$ ATPase products $(\mathrm{ADP}+\mathrm{P})$-induced activation of ATP-synthesis which is accompanied by the formation of endogenous $\mathrm{H}_{2} \mathrm{O}$ in cytoplasm. Besides, it is suggested that there is another pathway through ER activates mitochondrial function. It demonstrates the close contact between ER and mitochondria that is involved in maintaining a dynamic cross-talk between the two organelles [70]. ER-mitochondrial cross-talk is fundamental for the up-regulation of mitochondrial metabolism in stimulated cells and plays a key role in decoding $\mathrm{Ca}^{2+}$-mediated apoptotic signals [71].

It is known that in old animals because of high $\left[\mathrm{Ca}^{2+}\right]_{i}$, lipase $\mathrm{C}$ activity in membrane is increased. Previously it has been shown that there is a negative correlation between $\mathrm{Na}^{+} / \mathrm{K}^{+}$-ATPase activity and intracellular cAMP content and this correlation disappears upon the effect of lipase activation in membrane [72]. Therefore, it is suggested that $\leq \mathrm{nM}$ ouabain through stimulation of phosphatidylinositol cycle could lead to activation of inositol 1,4,5trisphosphate ( $\mathrm{InsP}_{3}$ )-induced $\mathrm{Ca}^{2+}$ efflux from ER and potentialdependent ${\mathrm{L}-\mathrm{Ca}^{2+}}^{2+}$ channels as a result of which $\left[\mathrm{Ca}^{2+}\right]_{\mathrm{i}-}$ Calmodulin-NO-cGMP-Ca ${ }^{2+}$ efflux cascade is stimulated [67]. The latter has an activation effect on $\mathrm{F} \mathrm{Na}^{+} / \mathrm{Ca}^{2+}$ exchange in cell membrane [68]. This suggestion is not final and needs more detailed investigation.

Thus, the obtained data allow us to suggest that the dysfunction of $\mathrm{a}_{3}$ isoform-dependent signaling system controlling cell hydration is a primary mechanism for generation of age-dependent neuronal dehydration and increase of $\left[\mathrm{Ca}^{2+}\right]_{\mathrm{i}}$.

\section{Acknowledgement}

We are grateful to Ani Gyurjinyan and Anna Sargsyan for editing the article.

\section{References}

[1] G. Casadesus, P.I. Moreira, A. Nunomura, et al, Indices of metabolic dysfunction and oxidative stress, Neurochem Res, 32 (2007) 717 722. http://dx.doi.org/10.1007/s11064-007-9296-y.

[2] D. Evans, Osmotic and ionic regulation: cells and animals, CRC Press: New York, 2009; 590

[3] E.K. Hoffmann, N.B. Holm, I.H. Lambert, Functions of volumesensitive and calcium-activated chloride channels, IUBMB Life, 66 (2014) 257-67. http://dx.doi.org/10.1002/iub.1266.

[4] L. Minkoff, R. Damadian, Biological ion exchange resins, X. The Cytotonus hypothesis: Biological contractility and the total regulation of cellular physiology through quantitative control of cell water, Physiol Chem Phys, 8 (1976) 349-87.

[5] G.M. Toney, Regulation of neuronal cell volume: from activation to inhibition to degeneration, J Physiol, 588 (2010) 3347-3348. http://dx.doi.org/10.1113/jphysiol.2010.197251.

[6] S.N. Ayrapetyan, on the physiological significance of the pumpinduced cell volume changes, Advances in Physiological Science neurobiology of Invertebrates, J. Salanki, 1980; 67-82.

[7] S.N. Ayrapetyan, V.L. Arvanov, on the mechanism of the electrogenic sodium pump dependence of membrane chemosensitivity, Comp Biochem Physiol, 64 (1979) 601-604. http://dx.doi.org/10.1016/0300-9629(79)90592-9.

[8] S.N. Ayrapetyan, M.A. Suleymanyan, A.A. Sagian, S.S. Dadalyan, Autoregulation of electrogenic sodium pump, Cel Mol Neurobiol, 4 (1984) 367-384

[9] S.N. Ayrapetyan, G.Y. Rychkov, M.A. Suleymanyan, Effects of water flow on transmembrane ionic currents in neurons of Helix 
pomatia and in Squid giant axon, Comp Biochem Physiol, 89 (1988) 179-186. http://dx.doi.org/10.1016/0300-9629(88)91076-6.

[10] R.G. Parton, K. Simons, The multiple faces of caveolae, Nat Rev Mol Cell Bio, 8 (2007) 185-194. doi: 10.1038/nrm2122. http://dx.doi.org/10.1038/nrm2122.

[11] V.A. Parsegian, R.P. Rand, D.C. Rau, Osmotic stress, crowding, preferential hydration and binding: a comparison of perspectives, Proc Natl Acad Sci USA, 97 (2000) 3987-3992. http://dx.doi.org/10.1073/pnas.97.8.3987.

[12] S. Ayrapetyan, M. Suleymanyan, H. Gevorgyan, G. Arakelov, The swelling as a protective reaction of cell, Reports Acad Sci USSR, 255 (1980) 111-115. (in Russian).

[13] D. Haussinger, The role of cellular hydration in the regulation of cell function, Biochem J, 313 (1996) 697-710. http://dx.doi.org/10.1042/bj3130697.

[14] G.I. McIntyre, Cell hydration as the primary factor in carcinogenesis: a unifying concept, Med Hypotheses, 66 (2006) 518-26. http://dx.doi.org/10.1016/j.mehy.2005.09.022.

[15] M. Secher, P. Ritz, Hydration and cognitive performance, J Nutr Health Aging, $16 \quad$ (2012) 325-329. http://dx.doi.org/10.1007/s12603-012-0033-0.

[16] H. Huang, F.I. Lu, S. Jia, et al, Amotl2 is essential for cell movements in zebrafish embryo and regulates c-Src translocation, Development,

134

(2007)

979-988. http://dx.doi.org/10.1242/dev.02782.

[17] K.R. Cooke, Ouabain and regulation of cellular volume in freshly prepared slices of rabbit renal cortex, J Physiol, 279 (1978) 361374. http://dx.doi.org/10.1113/jphysiol.1978.sp012349.

[18] S. Ayrapetyan, M. Sulejmanyan, on the pump-induced cell volume changes, Comp Biochem Physiol, 64 (1979) 571-575. http://dx.doi.org/10.1016/0300-9629(79)90585-1.

[19] D. Carpenter, M. Fejtl, S. Ayrapetyan, D. Szarowski, J. Turner, Dynamic changes in neuronal volume resulting from osmotic and sodium transport manipulations, Acta Biol Hung, 43 (1992) 39-48.

[20] S.N. Ayrapetyan, Na-K pump and $\mathrm{Na}$ :Ca exchanger as metabolic regulators and sensors for extraweak signals in neuromembrane, Modern problems of cellular and molecular biophysics, S.N. Ayrapetyan, A.C.T. North , Yerevan: Noyan Tapan, 2001; 31-57.

[21] F. Lang, Mechanisms and significance of cell volume regulation, J Am Coll Nutr, $26 \quad$ (2007) 613S-623S http://dx.doi.org/10.1080/07315724.2007.10719667.

[22] P. Hoffmann, T.J. Boeld, R. Eder, Loss of FOXP3 expression in natural human $\mathrm{CD}^{4+} \mathrm{CD}^{25+}$ regulatory $\mathrm{T}$ cells upon repetitive in vitro stimulation, Eur J Immunol, 39 (2009) 1088-1097. http://dx.doi.org/10.1002/eji.200838904.

[23] S.N. Ayrapetyan, Metabolically dependent fraction of membrane potential and electrode properties of the membrane of giant neurons in mollusks, Neuroscience Translations, 4 (1970) 53-57. http://dx.doi.org/10.1007/BF01126316

[24] R.C. Thomas, Electrogenic sodium pump in nerve and muscle cells, Physiol Rev, 52 (1972) 563-594.

[25] F. Lang, E.K. Hoffmann, Cell role of ion transport in control of apoptotic cell death, Compr Physiol, 2 (2012) 2037-2061. http://dx.doi.org/10.1002/cphy.c110046.

[26] A.L. Lehninger, Mitochondria and calcium ion transport, Biochem J, 119 (1970) 129-138. http://dx.doi.org/10.1042/bj1190129.

[27] A.L. Hodgkin, The conduction of the nervous impulse, Liverpool, UK, Liverpool University Press, 1964.

[28] S.N. Ayrapetyan, Cell hydration variation is a primary mechanism for intracellular signaling system, J Bioequiv Availab, 5 (2013) 136-141. http://dx.doi.org/10.4172/jbb.10000e35.

[29] S. Ayrapetyan, N. Baghdasaryan, Y. Mikayelyan, et al, Cell hydration as a marker for nonionizing radiation, Electromagnetic Fields in Biology and Medicine, M. Markov, USA: CRC Press, 2015; 193 215. http://dx.doi.org/10.1201/b18148-14.

[30] S. Ayrapetyan, A. Heqimyan, A. Nikoghosyan, Age-dependen brain tissue hydration, $\mathrm{Ca}$ exchange and their dose-dependent ouabain sensitivity, J Bioequiv Availab, 4 (2012 060-068. doi.org/10.4172/jbb.1000114.

[31] A. Heqimyan, L. Narinyan, A. Nikoghosyan, S. Ayrapetyan, Agedependent magnetic sensitivity of brain and heart muscles, Electromagnetic Fields in Biology and Medicine, M. Markov, USA CRC Press, 2015; 217-230. http://dx.doi.org/10.1201/b18148-15.

[32] R.A. Haworth, A.B. Goknur, H.A. Bertroff, Inhibition of Na-Ca exchange by general anesthetics, Circ Res, 65 (1989) 1021-1028. http://dx.doi.org/10.1161/01.RES.65.4.1021.

[33] K. Krnjevic, Cellular and synaptic actions of general anaesthetics, Gen Pharmacol, $23 \quad$ (1992) 965-975. http://dx.doi.org/10.1016/0306-3623(92)90274-N.
[34] A. Heqimyan, A. Deghoyan, S. Ayrapetyan, Ketamine - induced cell dehydration as a mechanism of its analgesic and anesthetic effects, J Int Dent Med Res, 4 (2011) 42-49.

[35] R. Dipolo, L. Beauge, Sodium/calcium exchanger: influence of metabolic regulation on ion carrier interactions, Physiol Rev, 86 (2006) 155-203. http://dx.doi.org/10.1152/physrev.00018.2005.

[36] R. Takahashi, M. Aprison, Acetylcholine content of discrete areas of the brain obtained by a near-freezing method, J Neurochem, 11 $(1964)$ 887-898. 4159.1964.tb06740.x.

http://dx.doi.org/10.1111/j.1471

[37] R.H. Adrian, The effect of internal and external potassium concentration on the membrane potential of frog muscle, J Physiol, 133 (1956) 631-658. http://dx.doi.org/10.1113/jphysiol.1956.sp005615.

[38] A.S. Keston, R. Brandt, The fluorometric analysis of ultramicro quantities of hydrogen peroxide, Anal Bioche, 11 (1965) 1-5. http://dx.doi.org/10.1016/0003-2697(65)90034-5.

[39] Z.S. Khachaturian, The role of calcium regulation in brain aging: reexamination of a hypothesis, Aging (Milano), 1 (1989) 17-34 http://dx.doi.org/10.1007/bf03323872.

[40] P. Kostyuk, E. Lukyanetz, Intracellular calcium signaling-basic mechanisms and possible alterations, Bioelectromagnetics: Current Concepts. NATO Science Series, S. Ayrapetyan, M. Markov, Dordrecht (Netherland): Springer Press, 2006; 87-122.

[41] M. Brini, E. Carafoli, Calcium pumps in health and disease, Physiol Rev, (2009) http://dx.doi.org/10.1152/physrev.00032.2008.

[42] P.F. Baker, M.P. Blaustein, A.L. Hodgkin, S.A. Steinhardt, The influence of calcium on sodium efflux in squid axons, J Physiol, 200 (1969) 431-458. http://dx.doi.org/10.1113/jphysiol.1969.sp008702.

[43] M.P. Blaustein, J. Zhang, L. Chen, H. Song, H. Raina, The pump, the exchanger, and endogenous ouabain: signaling mechanisms that link salt retention to hypertension, Hypertension, 53 (2009) 291298. http://dx.doi.org/10.1161/HYPERTENSIONAHA.108.119974.

[44] M. Juhaszova, M. Blaustein, $\mathrm{Na}^{+}$pump low and high ouabain affinity alpha subunit isoforms are differently distributed in cells, Proc Natl Acad Sci USA, 94 (1997) 1800-1805. http://dx.doi.org/10.1073/pnas.94.5.1800.

[45] M.P. Blaustein, W.J. Lederer, Sodium/calcium exchange: its physiological implications, Physiol Rev, 79 (1999) 763-854.

[46] F.A. Fuhrman, H.H. Ussing, A characteristic response of the isolated frog skin potential to neurohypophysial principles and its relation to the transport of sodium and water, J Cell Physiol, 38 (1951) 109-130. http://dx.doi.org/10.1002/jcp.1030380109.

[47] D.C. Tosteson, J.F. Hoffman, Regulation of cell volume by active cation transport in high and low potassium sheep red cells, J Gen Physiol, 44 (1960) 169-194. http://dx.doi.org/10.1085/jgp.44.1.169.

[48] A.A. Mongin, S.N. Orlov, Mechanisms of cell volume regulation and possible nature of the cell volume sensor, Pathophysiology, 8 (2001) 77-88. http://dx.doi.org/10.1016/S0928-4680(01)00074-8.

[49] A.S. Troshin, The membrane theory of cell permeability, Problems of Cell Permeability W.E. Widdas, Pergamon Press: Oxford, 1966; $5-27$

[50] G.H. Pollack, Phase transitions and the molecular mechanism of contraction, Biophys Chem, 59 (1996) 315-328.

[51] G.N. Ling, A convergence of experimental and theoretical breakthroughs affirms the PM theory of dynamically structured cell water on the theory's 40th birthday, Water and the Cell, G. Pollack, Netherlands: Springer, 2006; 1-52.

[52] S.N. Ayrapetyan, V.L. Arvanov, S.B. Maginyan, K.V. Azatyan, Further study of the correlation between Na-pump activity and membrane chemosensitivity, Cell Mol Neurobiol, 5 (1985) 231-43.

[53] I.V. Chizmakov, Z.A. Sorokina, Temperature-independence of the effect of osmotic pressure on the inward sodium current in the membrane of isolated spinal ganglion neurons of the rat, Neurophysiologiia, 18 (1986) 518-525. (in Russian).

[54] G. Rychkov, M.A. Suleymanyan, S.N. Ayrapetyan, Dependence of water flow effect on the ionic currents of dialyzed neuron of somatic membrane fluidity, Biol Membr, 6 (1989) 733-740. (in Russian).

[55] A. Macknight, A. Leaf, Regulation of cellular volume, Physiol Rev, 57 (1977) 510-573

[56] J.C. Skou, The influence of some cations on an adenosine triphosphatase from peripheral nerves, Biochim Biophys Acta, 23 (1957) 394-401.

[57] Z. Xie, A. Askari, $\mathrm{Na}^{+} / \mathrm{K}^{+}$-ATPase as a signal transducer, Eur J Biochem, 269 (2002) 2434-2439

[58] Z. Li, Z. Xie, The sodium pump and cardiotonic steroids-induced signal transduction protein kinases and calcium-signaling microdomain in regulation of transporter trafficking, Biochim Biophys Acta, 1802 (2010) 1238-1245. 
[59] K.J. Sweadner, Isozymes of the Na+/K+-ATPase, Biochim Biophys Acta, 988 (1989) 185-220.

[60] I. Berrebi-Bertrand, J.M. Maixent, G. Christe, L.G. Lelievre, Two active $\mathrm{Na}^{+} / \mathrm{K}^{+}$-ATPases of high affinity for ouabain in adult rat brain membranes, Biochim Biophys Acta, 1021 (1990) 148-156.

[61] K.M. McGrail, J.M. Phillips, K.J. Sweadner, Immunofluorescent localization of three $\mathrm{Na}^{+} / \mathrm{K}^{+}$-ATPase isozymes in the rat central nervous system: both neurons and glia canexpress more than one $\mathrm{Na}^{+} / \mathrm{K}^{+}$-ATPase, J Neurosci, 11 (1991) 381-391.

[62] N. Cholet, L. Pellerin, P.J. Magistretti, E. Hamel, Similar perisynaptic glial localization for the $\mathrm{Na}^{+} / \mathrm{K}^{+}$-ATPase alpha 2 subunit and the glutamate transporters GLAST and GLT-1 in the rat somatosensory cortex, Cereb Cortex, 12 (2002) 515-25.

[63] G.R. De Lores Amaiz, M.G. Ordieres, Brain Na (+), K (+)-ATPase activity in aging and disease, Int J Biomed Sci, 10 (2014) 85-102.

[64] A.A. Saghian, S.N. Ayrapetyan, D.O. Carpenter, Low concentrations of cuabain stimulate $\mathrm{Na}: \mathrm{Ca}$ exchange in neurons, Cell $\mathrm{Mol}$ Neurobiol, 16 (1996) 180-185.

[65] S.N. Airapetyan, Effect of temperature on membrane potential of giant neurons in snails. Neuroscience Translations, 3 (1969) 5-9.

[66] S.N. Ayrapetyan, The functional significance of electrogenic sodium pump in neurons, Problems of Brain Biochem, 9 (1974) 233 250. (in Russian).

[67] M. Hirata, F. Murad, Interrelationships of cyclic GMP, inositol phosphates, and calcium, Adv Pharmacol, 26 (1994) 195-216.

[68] K.V. Azatian, S.N. Ayrapetyan, D.O. Carpenter, Metabotropic GABA receptors regulate acetylcholine responses on snail neurons, Gen Pharmacol, 29 (1997) 67-72.

[69] E.A. Nagelhus, O.P. Ottersen, Physiological roles of Aquaporin-4 in brain, Physiol Rev, 93 (2013) 1543-1562.

[70] C. Giorgi, D. De Stefani, A. Bononi, R. Rizzuto, P. Pinton, Structural and functional link between the mitochondrial network and the endoplasmic reticulum, Int J Biochem Cell Biol, 41 (2009) 1817 1827.

[71] P. Pinton, C. Giorgi, R. Siviero, E. Zecchini, R. Rizzuto, Calcium and apoptosis: ER- mitochondria $\mathrm{Ca} 2+$ transfer in the control of apoptosis, Oncogene, 7 (2008) 6407-6418.

[72] S.N. Ayrapetyan, D.O. Carpenter, K.V. Azatian, S.S. Dadalian, D.M. Martirosyan, Extralow neurotransmitter dozes-induced triggering of neuronal intracellular messanger systems, Cellular Signalization, P.G. Kostyuk, M.A. Ostrovskii, Moscow: Nauka, 1992; 8996. 